\title{
Operational criteria in the justification of electrification of railway lines
}

\author{
Andrzej Massel ${ }^{1, *}$ \\ ${ }^{1}$ Railway Research Institute, ul. Chlopickiego 50, 04-275, Warsaw, Poland
}

\begin{abstract}
The process of electrification of the Polish railways took place from 1936 till early 1990s. Despite the political constraints of the post-war times, the decisions on electrification of particular sections of the railway network were usually based on economic factors. In 1970s and 1980s so called electrification thresholds were used to justify the need for electrification of railway line in question. They took into the number of tracks (single-track lines, double-track lines), terrain conditions (flat terrain, upland terrain) and the traffic structure (the share of passenger traffic) into account. In the framework of National Railway Program till 2023 (KPK) the realization of electrification projects have been undertaken again. The present paper deals with importance of the operational criteria in the decision-making concerning justification of electrification of railway lines. These criteria include the shortening of the journey times on particular sections, shortening of stops on the stations with the change of the type of traction, the savings of train operating companies resulting from the traction unification (change of demand for rolling stock and for workshops for its servicing), improvement of reliability and punctuality of services.
\end{abstract}

\section{Introduction}

Electrification of the Polish mainline railways started in the years 1936-1937 with the wiring of three line sections in the Warsaw Railway Node. The process of electrification was continued, although with changing intensity, till early 1990s. The largest growth rate has been observed in late 1980s. The total length of railway lines electrified between 1986 and 1990 has achieved $2485 \mathrm{~km}$, i.e. $497 \mathrm{~km}$ per year. The latest large electrification projects in Poland were finalized in 1994 and covered Klodzko - Miedzylesie (36 km) and Olsztyn - Elblag (99 km) sections. Further electrifications covered very short sections (usually newly built connections in agglomerations, for example airport links).

Despite the political constraints of the times after World War II, the decisions on electrification of particular sections of the railway network were usually based on economic factors. In 1970s and 1980s the economic evaluation was performed for one or a few representative sections characterised with typical traffic structure and average line profile, average distances between stops, average train weights and train speeds. So called electrification thresholds were used to justify the need for electrification of railway line in question. They took into the number of tracks (single-track lines, double-track lines), terrain conditions (flat terrain, upland terrain) and the traffic structure (the share of passenger traffic) into account. It is noteworthy, that these methods have been elaborated in COBiRTK (Central Unit for Railway Research \& Development), predecessor of Instytut Kolejnictwa (Railway Research Institute).

The European railways have recently been significantly transformed through implementation of the EU legislation imposing "unbundling", i.e. strict separation of infrastructure management and operation of passenger and freight services. Consequently, the approach for railway infrastructure investment appraisal has also been changed. It is also the case of electrification schemes. Relevant costs and benefits of such investment have to be allocated to particular stakeholders: infrastructure managers, train operating companies, competent authorities responsible for contracting public services.

The paper deals with the justification of electrification projects from the point of view of train operating companies (rail operators).

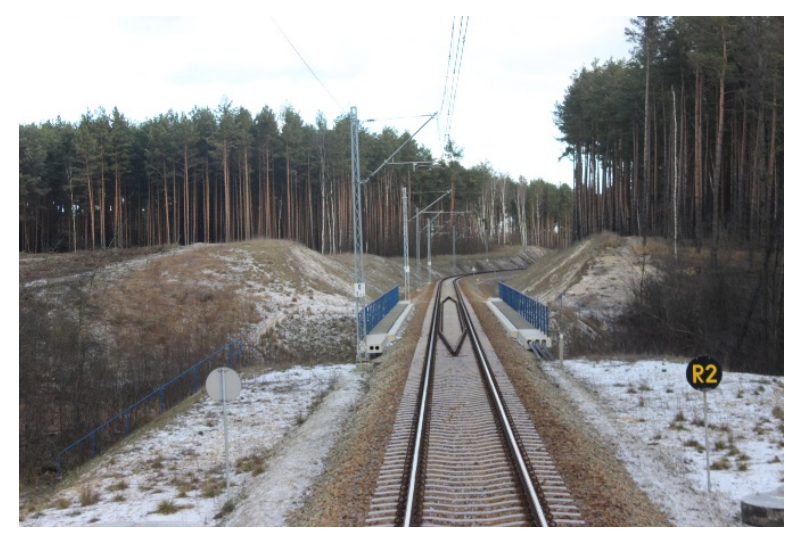

Fig. 1. Rail link in Czerwiensk completed in 2013.

\footnotetext{
* Corresponding author: amassel@ikolej.pl
} 


\section{Rail electrification projects in Poland}

According to the Annual Report of PKP PLK for the year 2016, the length of electrified railway lines is 11826 $\mathrm{km}$, while the total length of railways in operation is $18427 \mathrm{~km}$ [1]. This means that share of electrified railway lines in Poland equals to $64 \%$. The current shape of electrification in Poland cannot be treated as optimal, mainly due to the missing electrification of some parts of routes, important for passenger and/or freight transport. These missing links are "bottlenecks" in the railway network. They have been identified in the Report of ZNPK (Association of Independent Rail Operators), published in 2012 as major obstacles, inhibiting development of rail services across the country [2].

Table 1. Electrification projects in KPK till 2023.

\begin{tabular}{|c|c|c|}
\hline $\begin{array}{c}\text { Line } \\
\text { Nr. }\end{array}$ & Section & $\begin{array}{c}\text { Length } \\
{[\mathbf{k m}]}\end{array}$ \\
\hline 25 & Tomaszów Maz. - Opoczno & 26 \\
\hline 38 & Ełk - Korsze & 99 \\
\hline 68 & Lublin - Stalowa Wola Rozwadów & 103 \\
\hline 71 & Ocice - Rzeszów & 66 \\
\hline 201 & Maksymilianowo - Gdynia & 171 \\
\hline 214 & Somonino - Kartuzy & 8 \\
\hline 229 & Glińcz - Kartuzy & 11 \\
\hline 274 & Lubań Śląski - Zgorzelec & 24 \\
\hline 278 & Węgliniec - Zgorzelec & 26 \\
\hline 409 & Szczecin Gumieńce (- Tantow) & 10 \\
\hline
\end{tabular}

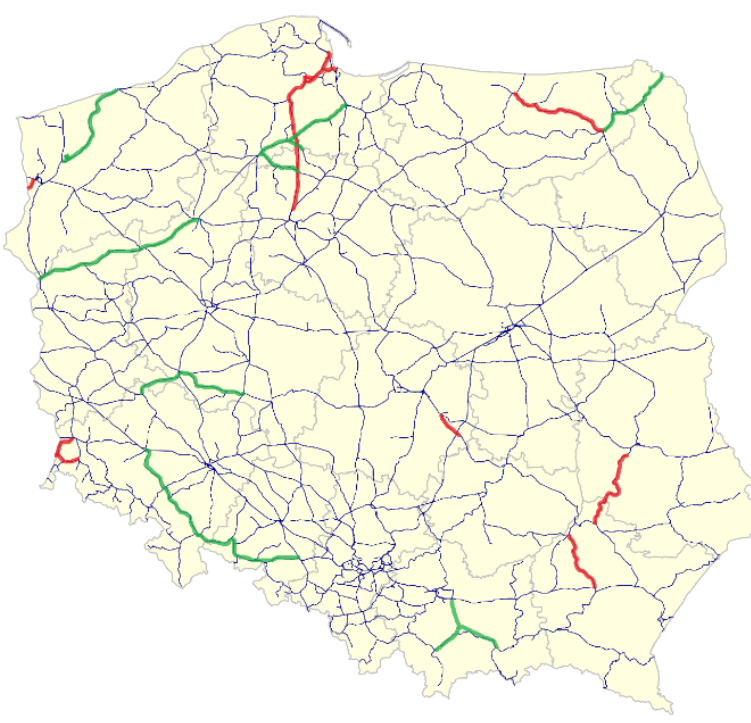

Fig. 2. Electrification projects included in KPK till 2023 (red) and at the planning stage (green).
The process of electrification of railways in Poland, has recently been started again. There are several electrification projects underway, included in KPK (National Railway Program) till 2023 (Table 1) [3]. The total length of existing lines covered with these projects exceeds $500 \mathrm{~km}$. Moreover several kilometres of new tracks will be electrified. Several railway upgrading projects include double-tracking or construction of new tracks, for example between Gdynia Chylonia and Słupsk on line nr 202 and between Kraków and Kraków Bieżanów in Cracow railway node. Electrification investments are also planned for coming years. They are in the planning process, including elaboration of feasibility studies for particular projects (Table 2 and Fig.2).

Table 2. Major electrification projects under study.

\begin{tabular}{|c|c|c|}
\hline $\begin{array}{c}\text { Line } \\
\text { Nr. }\end{array}$ & Section & $\begin{array}{c}\text { Length } \\
{[\mathbf{k m}]}\end{array}$ \\
\hline 14 & Krotoszyn - Leszno - Głogów & 116 \\
\hline 39,41 & Ełk - Suwałki & 71 \\
\hline 51 & Suwałki - Trakiszki & 29 \\
\hline 68 & Lublin - Stalowa Wola Rozwadów & 103 \\
\hline 137 & Kędzierzyn Koźle - Legnica & 219 \\
\hline 203 & Piła - Krzyż - Kostrzyn & 161 \\
\hline 203 & Tczew - Czersk - Chojnice & 97 \\
\hline 208 & Wierzchucin - Chojnice & 44 \\
\hline 215 & Śliwice - Szlachta - Czersk & 15 \\
\hline 402 & Kołobrzeg - Goleniów & 100 \\
\hline
\end{tabular}

\section{Related works}

Methods for analysis of costs and benefits of switching to electrical traction can be found in several publications. First of all it is necessary to mention the Polish works from 1970s and 1980s, in which analyses were based on (so called) electrification thresholds. These thresholds were used to establish the order, in which particular railway lines should be electrified and to define the rational scope of electrification of the national railway network [4],[5].

Various aspects of railroad productivity that might be influenced by the adoption of electrified operation of railways were evaluated by Ditmeyer et al. Productivity was considered from the viewpoint of motive power, transportation economics, signaling and train control, and railway operations [6]. Good example of cost-benefit analysis for railway electrification is presented in the paper by Al-Tony et al. [7]. The paper examines the economic and financial viability of a proposed electrification scheme for the Cairo-Alexandria railway 
line. The framework of appraisal developed identifies the potential direct and indirect benefits of the scheme, and its costs.

The research team from Gdansk University of Technology proposed complex model for calculating economical threshold for railway line electrification taking the factors regarding constant and variable cost, such as a dynamics of the train or energy prices into account [8].

The paper by Kirkwood et al deals with the typical problems Overhead Line Equipment projects face, when analysing the best option for overbridges. The three competing options (bridge rebuild, track lowering, reduced clearance) have very different capital expenditure (CAPEX) and operating expenditure (OPEX) costs. A model was elaborated to predict these costs over the anticipated assessment period [9].

In the study of rail freight electrification for Southern California, the three key electrification technologies were analysed: straight-electric (with catenary on the entire line); dual-mode (with catenary on some sections); and a linear synchronous motor (LSM) system. These three technology alternatives and each geographic option within each alternative are evaluated based on technology readiness, railroad operations impacts, total capital cost, energy cost savings and total emissions reduction in the region [10].

\section{Impact on operations}

Very important factor from operational point of view seems to be the flexibility of rolling stock utilisation. Therefore every point of the network, at which changeover from electric traction to diesel traction (or vice versa) occurs, forms significant problem for railway operators due to:

- need for change of the locomotive (passenger and freight trains), or

- need for change of the train (passenger trains).

Every change of rolling stock (electric locomotive versus diesel locomotive, EMU versus DMU) usually generates additional cost for the train operating company, due to need for dedicated infrastructure for servicing traction units (workshops) and for personal at these locations.

The change of locomotive from electric to diesel one (or vice versa) imposes extended stopping time at involved station. Typical time for change of the locomotive (in case of the passenger train) was traditionally around 8-10 minutes. However in case of the new generation of locomotives this time can be extended up to 20 minutes or even more, due to the need for turning off the diesel engine, switching off all onboard computer systems, protecting against electric shock, etc. (Fig.3). The 20 minutes of time waste for the change of the locomotive can be compared with journey time difference, resulting from modernisation of $160 \mathrm{~km}-$ long railway line with speed increase from $120 \mathrm{~km} / \mathrm{h}$ to $160 \mathrm{~km} / \mathrm{h}$.

Typical example of problems resulting from changing locomotives is the situation that occurred after diverting Warsaw - Lublin train services (closed for modernisation) from original route to alternative route via Łuków in June 2017. The stopping times for switching the locomotive from electric to diesel (12-14 minutes) have proved to be inadequate and caused significant delays of trains. Therefore starting from September 3 these times were extended to 20-34 minutes to guarantee timekeeping.

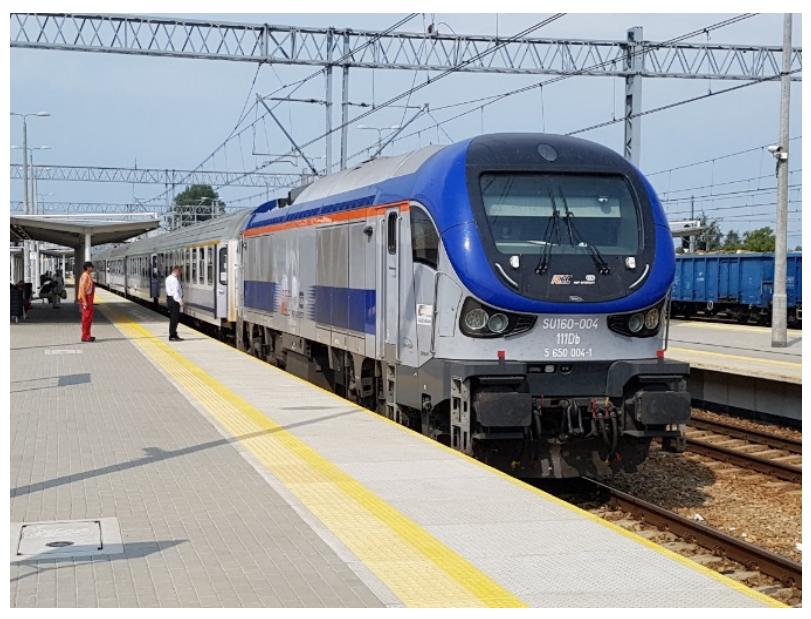

Fig. 3. The change of the locomotive on Warsaw - Lublin route.

Another possibility at traction change location is to arrange connection from electric train (operated with EMU) to the diesel one (DMU). In that case some time (usually a few minutes, depending on the layout of the platforms on the station) is necessary for passengers to move from one train to another one (Fig.4). Apart from wasting of time, such change can form inconvenience for passengers, particularly for elderly people, as well as for passengers with reduced mobility (PRM).

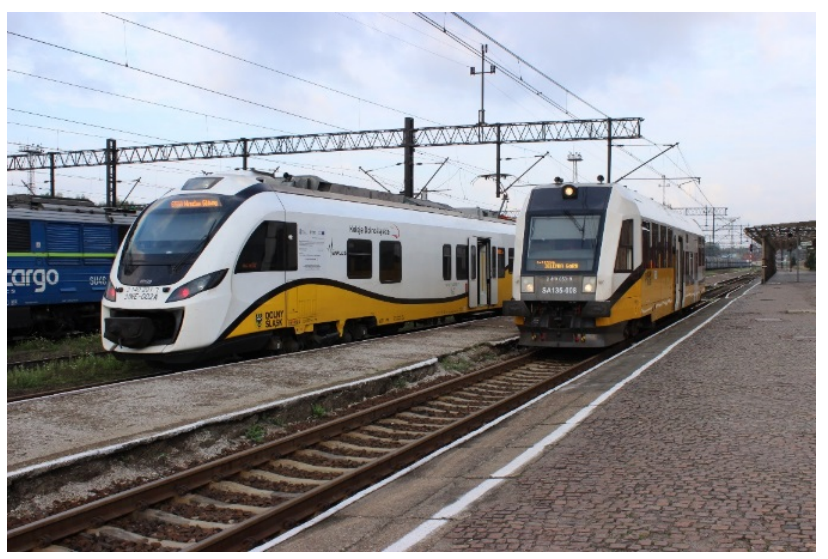

Fig. 4. The change of the train at Węgliniec station (Wrocław Zgorzelec route).

The example of station, where change of train is necessary due to lack of electrification of the final section of the line is Weggliniec in Lower Silesia. Passengers travelling from Wrocław to Zgorzelec change there from electric train (operated with EMU) to the diesel one. Such transfer connections are offered 8 times a day in each direction and a typical time for change is 5 - 
16 minutes (according to timetable valid from June 2017).

As an alternative for electrification, if travel times are very important, more expensive locomotives with dual mode engines can be used. However from operational point of view, the most practical solution would be uniform traction on entire network $(100 \%$ of electric traction, $100 \%$ of diesel traction). Time losses related to the change of traction can be accepted only in cases of routes with very small traffic. Therefore it is quite understandable, that in several cases a main reason for electrification of particular section is compatibility of the network. When electrifying a line, the connections with other railway lines should be considered. It is noteworthy, that those connections are particularly important in case of traffic disruptions on railway lines and they allow for diverting trains to alternative routes without need for other traction unit.

The good example for importance of alternative electrified routes is the case of traffic breakdown on the Karlsruhe - Basel main line in southwest Germany, one of Europe's key rail freight arteries. The line had to be closed from August 12 till October 2 following a major earth movement caused by groundwater entering the construction site of the new tunnel being built under Rastatt [11]. The double-track section between Rastatt and Baden Baden is already a major bottleneck on this very busy main line, which is used by up to 200 freight trains a day plus over 100 regional and international passenger services. Due to lack of alternative electrified route, huge disruption occurred, involving re-routing of all freight trains through France and substitution of passenger trains (including long-distance trains) with buses.

\section{Proposal for operational criteria}

In order to assess the effectiveness of the infrastructure investment it is necessary to carry economic analysis. The principles for such analysis are given for example by Dyr et al [12]. However in assessing the need for electrification of particular line segment it seems absolutely necessary to cover essential operational factors in CBA analysis. The following factors can be taken into account:

- the number of trains operated on the segment,

- the number of trains running through from (or to) electrified part of the network,

- the passenger flows on the segment,

- the number of transfer connections from (or to) electrified part of the network,

- the typical time necessary for changing locomotive from electric to diesel one,

- the average time for passenger to change from dieseloperated train to the electric one (and v.v.),

- journey time difference (diesel traction versus electric traction) for all types of trains operated on the line segment and for all stopping patterns),

- existence of alternative routes (electrified, notelectrified).
The electrification brings several benefits for passengers, especially due to reduction of stops at the stations with change of traction and due to shortening of journey times thanks to better traction characteristics of electric locomotives (in comparison to diesel ones) and of EMUs (in comparison to DMUs). The scale of benefits for passengers can be illustrated with the following example.

Let us assume, that the traction change is necessary on given long-distance route. The characteristics of the service is as follows:

- 8 trains per day in each direction,

- 200 passengers per train,

- structure of motivation of journey: $20 \%$ duty journeys, $20 \%$ journeys to/from work, $60 \%$ other reasons,

- stopping time for change of the locomotive (dieselelectric, electric-diesel): 20 minutes

- stopping time necessary for passengers: 2 minutes,

- journey time difference (electric vs. diesel): 10 minutes.

To calculate economic benefits resulting from shortening of the train journey it is necessary to assume unit values of time. According to Jaspers Blue Book for Public Transport project appraisal those values for Poland are as follows:

- $68,46 \mathrm{PLN} / \mathrm{h}$ for duty journeys,

- $33,73 \mathrm{PLN} / \mathrm{h}$ for journeys to or from work,

- 28,30 PLN/h for other journeys.

Estimated benefit resulting only from shortening of the journey for analysed train service is around 16,7 million PLN per year.

The savings of train operating companies resulting from the traction unification are:

- the change of demand for rolling stock, due its better utilisation (more trainkilometres per vehicle),

- the change of demand for workshops for rolling stock servicing,

- the change of demand for train personnel.

Another benefit (for passengers and for train operators) is the improvement of reliability and punctuality of services.

\section{Conclusions}

The mainline electrification projects have recently been undertaken in Poland after around 20 years period of stagnation. In the meantime the railway environment has significantly been changed. According to the EU directive, the railway undertakings have been separated from infrastructure managers. The needs of the train operating companies must be taken into account at the stage of planning of railway investment. It is necessary to enhance methods of economic assessment of railway electrification projects.

CBA analyses should not be restricted to short sections in question only. They should rather take costs and benefits of operators, resulting from switching to electric traction on larger area (entire regions) into account. 


\section{References}

1. PKP PLK, Annual Report 2016, (Warsaw, 2017)

2. ZNPK, Bottlenecks on the Polish railway network. (ZNPK, Warszawa, 2012) [in Polish]

3. Krajowy Program Kolejowy do 2023 roku (National Railway Program till the year 2023), (Warszawa, 2015)

4. S. Kuczborski, Z. Polak, W. Wasilewicz, Criteria for the order of electrification of railway lines, Przegląd Komunikacyjny, 5, 3-11 (1974) [in Polish].

5. K. Kożuchowski, Z. Polak, W. Wasilewicz, Necessary scope of railway electrification in the current situation in fuel and power supply), Przegląd Komunikacyny, 1, 8-16 (1980) [in Polish]

6. S. Ditmeyer, J. Martin, P. Olson, M. Rister, B. Ross, J. Schmidt, E. Sjokvist, Railway electrification and productivity: A Study report, Transportation Research Record 1029, 23-30 (1985)

7. F. Al-Tony, A. Lashine, Cost-benefit analysis of railway electrification: case study for CairoAlexandria railway line, Impact Assessment and Project Appraisal, 18:4, 323-333 (2000)
8. M. Tomczyk, M. Pacholski, K. Karwowski, Comprehensive modelling of the cost effectiveness of railway line electrification. Zeszyty Naukowe Wydziału Elektrotechniki i Automatyki PG, 51, 197-200 (2016).

9. I. Kirkwood, L. Giuntini, E. Shebab, P. Baguley, Development of a Whole Life Cycle cost model for electrification options on the UK rail system. Procedia CIRP, 47, 1-5, (Elsevier, 2016).

10. Comprehensive Regional Goods Movement Plan and Implementation Strategy. Task 8.3: Analysis of Freight Rail Electrification in the SCAG Region. Southern California Association of Governments, (Cambridge Systematics, 2012)

11. A. Green, $D B$ and $S B B$ seek to minimize Rastatt closure disruption. International Railway Journal, http://www.railjournal.com/index.php/europe/dband-sbb-seek-to-minimise-rastatt-closuredisruption.html?channel=537

12. T. Dyr, P. Kazubek, Assessment of transport infratsructure investment co-financed from EU funds, (Spatium, Radom, 2011) [in Polish] 